PORTIONS OF THIS REPORT ARE ILTEGIBLE. It has been roproduced from the best available copy to permit the broadest possible availability.

\title{
Detailed Plan for the Decontamination and Restoration of the 231-Z Facility
}

March 1976

Prepared for the U.S. Energy Research and Development Administration under Contract E(45-1):1830 


\section{DISCLAIMER}

This report was prepared as an account of work sponsored by an agency of the United States Government. Neither the United States Government nor any agency Thereof, nor any of their employees, makes any warranty, express or implied, or assumes any legal liability or responsibility for the accuracy, completeness, or usefulness of any information, apparatus, product, or process disclosed, or represents that its use would not infringe privately owned rights. Reference herein to any specific commercial product, process, or service by trade name, trademark, manufacturer, or otherwise does not necessarily constitute or imply its endorsement, recommendation, or favoring by the United States Government or any agency thereof. The views and opinions of authors expressed herein do not necessarily state or reflect those of the United States Government or any agency thereof. 


\section{DISCLAIMER}

Portions of this document may be illegible in electronic image products. Images are produced from the best available original document. 


\section{NOTICE}

This report was prepared as an account of work sponsored by the United States Governm snt. Neither the United States nor the United States Energy Research and Development Administration, nor any of their employees, nor any of their contractors, subcontractors, or their employees, makes any warranty, express or implied, or assumes any legal liability or responsibility for the accuracy, completeness or usefulness of any information, apparatus, product or process disclosed, or represents that its use would not infringe privately owned rights.

\section{PACIFIC NORTHWEST LABORATORY} operated by

BATTELLE

for the

U.S. ENERGY RESEARCH AND DEVELOPMENT ADMINISTRATION

Under Contract E(45-1)-1830

Printed in the United States of America Available from

National Technical Information Service

U.S. Department of Commerce 5285 Port Royal Road

Springfield, Virginia 22151

Preve: Printer Copy 35.50 ; Microfiche $\$ 2.25$ 

by
R. R. King
V. C. Nsmund
H. L. Butts

March 1976

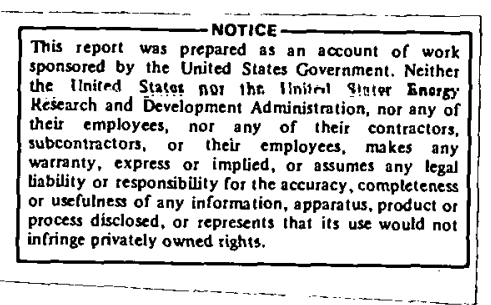

This report was prepared as an account of work
sponsored by the United Staes

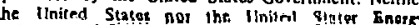

kesearch and Development Administration, nor any of

subcontractors, or their employees, makes any

warranty, express or implied, or assumes any legal

or usefulnes of any information accuracy, compleceness

process disclosed, or represents that its use would not infringe privately owned sights.

\section{Battelle}

Pacific Northwest Laboratories

Richland, Washington 99352 
THIS PAGE

\section{WAS INTENTIONALLY LEFT BLANK}




\section{CONTENTS}

1.0 INTRODUCTION

2.0 OBJECTIVE AND SCOPE OF ACTIVITIES

3.0 RESPONSIBILITIES 3

4.0 GENERAL CRITERIA 5

5.0 PLAN 9

5.1 Facility Description - 9

5.2 Exit Routes - Description and Preparation 9

5.3 Glove Box Preparation 12

5.4 Glove Box Removal ' 13

5.5 Exhaust System and Service Lines Removal 15

5.6 Contaminated Drainage System Removal/Containment 76

5.7 Obsolete Equipment Disposal 16

5.8 Alarm Systems Removal 16

5.9 Facility Restoration 17

$\begin{array}{ll}6.0 \text { SPECIAL CONSIDERATIONS } & 19\end{array}$

6.1 Security - 19

6.2 Radiation Protection 19

6.3 Ventilation and Air Balance 20

6.4 Criticality Safety 20

$\begin{array}{lll}6.5 \text { Alarm Systems } & 21\end{array}$

6.6 Nuclear Materials Management 21

6.7 Property Disposal 21

6.8 Project Management 21

7.0 TIME SCHEDULE AND COST ESTIMATE 23

8.0 WORKING REFERENCE DOCUMENTS 25

ATTACHMENTS

Attachment 1, First Floor Arrangement, 231-Z Building

Attachment 2, First Floor Equipment Exit Routes

Attachment 3, Duct Level Equipment Exit Routes 
Attachment 4, Summary of Glove Boxes to be Removed: Dimensions and Exit Routes

Attachment 5, Sequence and Estimated Completion Schedule of Activities

Attachment 6, Sample Check Sheets

Attachment 7, Cost/Schedule Data

Attachment 8, Work Schedule. 


\section{DETAILED PLAN FOR THE DECONTAMINATION AND RESTORATION \\ OF THE 231-Z FACILITY}

\subsection{INTRODUCTION}

In January 1975, Battelle, Pacific Northwest Laboratory (PNL) was advised by the Division of Military Application (DMA) of their intention to phase out the General Weapons Development Program. The program has been conducted by PNL Materials Department in the 231-Z Building, 200-W Area of the Hanford Reservation. In addition to the phaseout of the research program, a commitment was made to decontaminate and restore the $231-Z$ facility for use as a nonplutonium ERDA laboratory.

\subsection{OBJECTIVES AND SCOPE OF ACTIVITIES}

The objectives of the decontamination and restoration project are:

- Complete removal of all glove boxes and related plutonium processing equipment including ventilation systems, drainage systems, and other obsolete service systems.

- Decontamination of the facility to the extent that future laboratory operations may be conducted without Radiation or Controlled-Zone restrictions.

- Restoration of the facility to such condition as renders it fit for use as a laboratory.

- Program phaseout and decontamination and restoration activitics planned to reasonably assure uninterrupted operation of other ongoing research and development programs. 
THIS PAGE

WAS INTENTIONALLY

LEFT BLANK 


\subsection{RESPONSIBILITIES}

Battelle-Northwest shall have responsibility for:

- The management of the total project.

- The preparation of a sufficiently detailed plan to meet project objectives.

- Radiation protection activities.

- Deactivation of glove boxes and related equipment including draining and disposal of contaminated hydraulic and vacuum pump oil.

- Criticality safety evaluations.

- Burial vault procurement.

- Providing design criteria as needed by other contractors.

- Property accounting records.

- Physical security and safeguards.

- Final review and updating of facility drawings.

- Nuclear materials management and accountability.

- Providing guidarice to assure safety of operations.

- Historical records and documentation.

- Reports.

The J.A. Jones Construction Company (JAJ) shal1:

- Safely remove deactivated and obsolete equipment from the laboratory.

- Package removed equipment in the burial vaults.

- Transport the filled and sealed burial vaults to the burial sites.

- Perform cleanup and restoration activities.

The Atlantic Richfield Hanford Company (ARHCO) shall bury solid wastes.

NOTE: PNL shall prepare the necessary burial records and shall be responsible for scheduling and coordinating the transfer of filled burial vaults to the burial sites. 
THIS PAGE

\section{WAS INTENTIONALLY LEFT BLANK}




\subsection{GENERAL. CRITERIA}

All activities associated with the decontamination and restoration of the 231-Z facilities shall meet the following criteria:

1. The disposal of contaminated materials and equipment shall be in accordance with ERDA Manual Chapter 0511 "Radioactive Waste Management"; ARHCO Document ARH-3032, Specifications and Standards for the Packaging, Storage, and Disposal of Richland Operations Solid Wastes; and standard property disposal procedures.

2. Flammable solvents and loose combustibles shall be removed from glove boxes and prepared for disposal or recovery using standard facility procedures.

3. Hydraulic or vacuum oil in equipment to be buried shall be drained, immobilized, and packaged for burial as solid waste in accordance with current facility procedures.

4. Burial boxes shall be Fiberglass Reinforced Polyester (FRP) covered plywood in accordance with the following Automation Industries, Inc., Vitro Engineering (AII-V) drawings and AII-V procurement specification CE-0948-PI.

$$
\begin{aligned}
& \text { H-2-27440, Sheets } 1-4 \\
& \text { H-2-27441, Sheets } 1-3 \\
& H-2-27442 \text {, Sheets } 1-4 \\
& \text { H-2-27445, Sheets } 1-3
\end{aligned}
$$

Approved steel or reinforced concrete burial boxes may be used where weight or other unique conditions warrant the use of the more expensive container.

5. Containers used in the transportation of radioactive materials shall be approved in accordance with ERDA Manual Chapter 0529, "Safety Standards for Packaging of Fissile and Other Radioactive Materials." 
6. The fissile material content of glove boxes and equipment to be buried shall be at the lowest practical level. Disposal approval shall be requested for every glove box and the request shall specify glove box holdup value and method of measurement.

7. Every glove port and bag port on the glove box shall be covered with a suitable cover taped in place. Glove boxes are expected to be free of external smearable contamination.

8. The 200-Area Fire Department shall be notified prior to deactivatfon of every glove box fire detector.

9. Lead glass or nther exterior glove box attachments may be removed and salvaged provided the criteria of Procedure 6 , BNWL-MA-6 are met.

10. The packaging of glove boxes and equipment in burial boxes shall be planned to minimize the void volume in each burial box and to minimize the total volume of transuranic waste buried. Glove boxes shall be sectioned, if necessary, to meet this criterion. Sectioned glove boxes shall be blanked with metal plates.

11. The packaging of glove boxes and equipment into the burial boxes shall be performed outside the building and only during satisfactory weather conditions. Project management shall judge whether wind and/or rain conditions would create a safety hazard.

12. Unprotected glove boxes shall not be stored outside the building.

13. Interior walls that are permanently removed may be released by Radiation Monitoring and transported to the Central Landfill Facility for disposal provided the requirements of Procedure 6, BNWL-MA-6 are met.

14. Painted service lines or ductwork free of external contamination but that cannot be unconditionally released by Radiation Monitoring shall be transported to the Industrial waste Trench for burial. 
15. Equipment or material unconditionally released by Radiation Monitoring may be excessed through standard PNL property disposal procedures.

16. Laboratory rooms shall be decontaminated to levels established by PNL's Occupational and Environmental Safety Department. The following decontamination standards shall apply:

- Maximum smearable Zero

- Maximum fixed (unpainted) $0.1 \mu \mathrm{Ci} / 100 \mathrm{~cm}^{2}(220 \mathrm{~d} / \mathrm{m})$

- Maximum fixed (under paint) $10 \mu \mathrm{Ci} / 100 \mathrm{~cm}^{2}(22,000 \mathrm{~d} / \mathrm{m})$

Decontamination shall not arbitrarily stop when these levels are attained. The lowest practical level of contamination shall be sought. Contaminated areas shall be thoroughly documented for easy identification by future building occupants.

17. The physical security of the building shall be maintained at all times. Equipment exit routes that require door or wall removal shall be either positively sealed during nonworking hours or monitored under fulltime security guard surveillance.

18. The Facility Manager shall approve all cutting and welding operations.

19. The laboratory fire protection system (detectors and sprinklers) shall remain in service or a fire watch shall be established. 


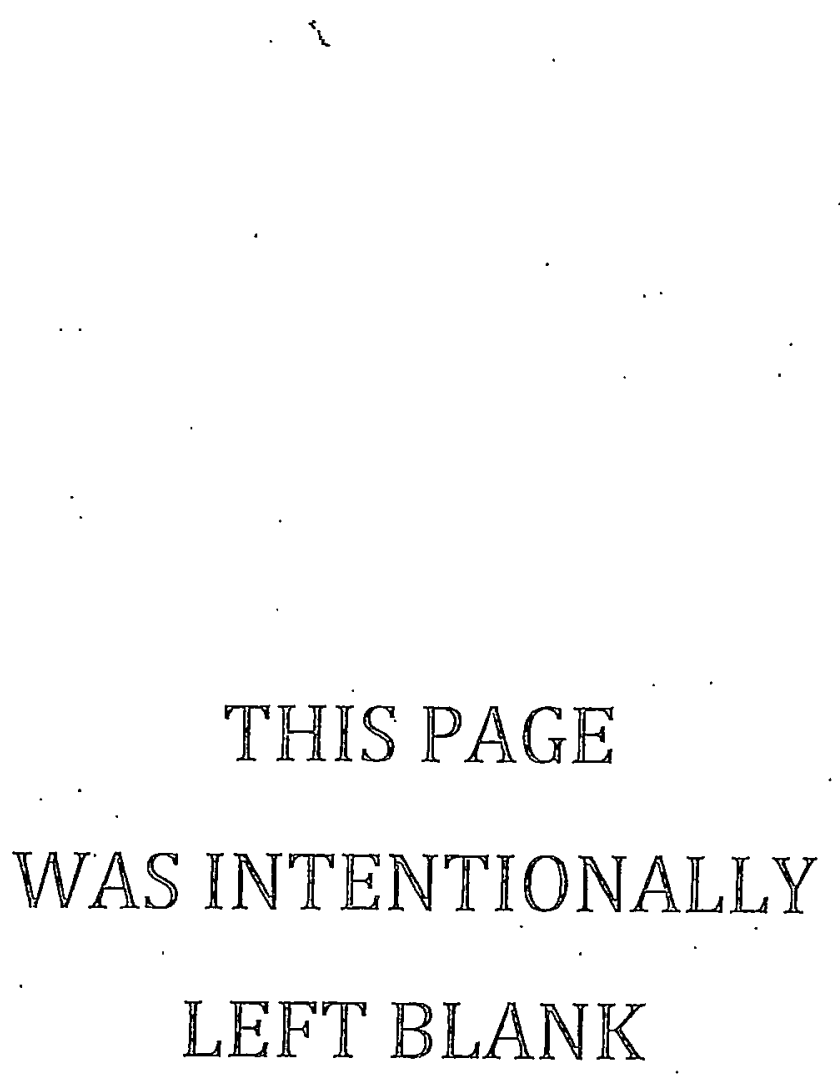




\subsection{PLAN}

\subsection{FACILITY DESCRIPTION}

The 231-Z Building is located within the "Z" Exclusion Area inside the Hanford 200-West Area. The Exclusion Area is fenced and access to the area is controlled. Continuous accountability of personnel within the " $Z$ " Exclusion Area is maintained by plant security forces.

The two-story 231-Z Building consists of reinforced concrete and concrete block construction. The building is designed to withstand 100-mile per hour wind loads, and earthquake shocks of intensity VII on the modified Mercalli Scale of 1931. The first floor is used for the research work and is shown on Attachment. 1. The second floor, one large open bay with floor area of approximately 23,500 square feet, is used for piping, ventilation and support services for the first floor. The building has a total floor area of 51,000 square feet with 21,700 square feet of process area. In addition to the main laboratory structure there is a 3,000-square foot office extension of concrete block construction. The office building is attached to the laboratory structure and isolated by air locks.

The 231-Z Building is utilized for metallurgical research on plutonium and its alloys and for fabrication development work on plutonium components. Large quantities of plutonium are routinely handled and stored in connection with the research program.

\subsection{EXIT ROUTES - DESCRIPTION AND PREPARATION}

Eleven exit routes, shown in Attachments 2 and 3, will be used. These exit routes provide for the most efficient removal of facility equipment and for the least disruption to ongoing programs.

Route 1 proceeds north between column lines $B$ and $C$ and exits the building through security door 6 . The walls and ceiling of Room 7A will be permanently removed. The door between corridor " $A$ " and Room 7A must be modified and included in security alarm circuit 5 . 
Route 2 is required to accommodate the larger glove box sections from Rooms 1,2 , and 4 . Route 2 proceeds north in corridor "A", enters Room 7 by removing wall panels located between column lines 8 and 10, and exits the building through security door 6 . Either the opening between corridor "A" and Room 7 must be sealed offshift or fulltime security guard surveillance provided.

Route 3 permits removal of the smaller items from the vaults and from Rooms $1,2,3$, and 4 . Route 3 proceeds north in corridor. "A" and exits the building through security door 7 .

Route 4 provides for the removal of glove hoxes and equipment from Rooms $6 \mathrm{~A}$ and $6 \mathrm{~B}$. A framed block section must be removed from the north wall of Room $6 B$ adjacent to column 7 ine $E$. The wall between Rooms $6 A$ and 6B will be permanently removed. The equipment removal will proceed through the panel opening into Room 51, through Room 51 double doors into corridor "B" and will exit the building north through corridor "B". Either the opening between Rooms $6 B$ and 51 must be sealed offshift or fulltime security guard surveillance provided.

Route 5 proceeds north in corridor " $\mathrm{B}$ " and exits the laboratory through security door 8 . Glove boxes and equipment from Rooms 5, 15, 16, 28 , and 31 will be removed by this route.

Route 6 provides for the removal of equipment from Rooms 48 and 50 through security door 9 located in Room 50 adjacent to column line $M$. The door must be removed and the opening enlarged in order to remove glove box 50-4. Either the opening must be sealed offshift or full-time security surveillance provided. When the equipment removal is completed the outside door will not be replaced. The wall opening will be permanently sealed. The walls between Rooms 48 and 50 will be permanently removed.

Route 7 is the major equipment removal path of the project. Glove boxes and equipment from Rooms 46, 47A, 47B, 47C, 18, 19,33,34, 36, and 37 will be removed by this route. The route proceeds east in corridor "D" 
and exits the building through security door 11 . Security door 11 is presently a single door. Prior to removing equipment via Route 7 the opening must be enlarged and the door replaced with double doors and a removable overhead panel. The internal walls separating Rooms 46, 47A, 47B, 47C, and Room 49 will all be permanently removed. The door and adjacent metal panel between Room 49 and corridor "D" will be removed and replaced with double doors. The walls forming Room 19 and Room 25 will be permanently removed, as will the wall separating Rooms 34 and 36 . The door and adjacent panel between Room 37 and corridor "D" must also be removed and replaced" with double doors. None of the walls to be removed are load-bearing walls.

Route 8 provides for removal of equipment from Rooms 41 and 45 and for removal of glove box 39-1. The framed block panel on the east wall of Room 45 must be temporarily removed and the walls between Rooms 41, 45, and Room 39 will be permanently removed. Either the opening in the east wall of Room 45 must be sealed offshift or fulltime security guard surveillance provided.

Note: Equipment removal via Route 8 is planned approximately one year prior to that described for Route 9 . It will be necessary to partition Room 39 to isolate both radioactive materials and classified materials from restoration work proceeding in the north section of Room 39.

Route 9 will be used to remove the last active glove boxes and equipment from the first floor laboratory area. The removal route will be through an opening provided in the east wall of Room 39 by removing the wall above security door 13. At this stage of the project, the nuclear material inventory will have been disposed and all work on classified programs terminated. Off-shift control of the wall opening will then conform to specified security requirements at the time.

Route 10, illustrated in Attachment 3, provides for the removal of all equipment, ductwork and obsolete service lines from the duct level except 
the contaminated gas recirculating system located above Room 1. The exit route proceeds east through the service doors located between column lines 3 and 5 .

Route 11 will be used to remove the contaminated gas recirculating system located above Room $T$, since building ventilation ductwork prevents use of Route 10. A section of the block wall in column line 3 between lines $D$ and $E$ must be temporarily removed. The removal route will proceed through the wall opening, then west along column line 2 to the southwest corner service doors and out the doors onto the first floor roof. A crane will be used to lower the system to ground level.

\subsection{GLOVE BOX PREPARATION}

Glove boxes shall be removed from service and prepared for burial by completing the following tasks, as appropriate:

- Inspect a11 packages and containers for fissile material.

- Remove all combustibles from the glove box and package in approved 55-gallon drums. Process the drums for burial or recovery using standard facility procedures.

Note: If special packayes or containers are required for the plutonium-contaminated waste, new criticality safety limits may be required.

- Rigidiy secure equipment and fixtures that may create a safety hazard during movement of the glove box out of the building and during packaging in the burial vault.

- Examine each glove box using the analytical procedures estatitished by ARHCO during removal of the DMA equipment from the 234-5 Building. Do not complete removal of the glove box until disposal of the plutonium holdup value assigned by this technique has been accepted by appropriate PNL authorities and approved by ERDA. 
Note: If a plutonium deposit in excess of the former glove box limit is discovered, a special criticality safety procedure may be necessary. Upon discovery of such a plutonium deposit, work sha.l be halted at that work station until a criticality safety analysis of the situation is made and proper controls estaitished.

- Drain the oil from hydraulic, vacuum, and refrigeration systems. The oil may be uncontaminated or contaminated, or may contain a recoverable quantity of plutonium. Sample as necessary to determine the proper disposal procedure.

- Salvage lead glass and other exterior attachments as appropriate.

- Five glove boxes $(1-3,2-3,2-4,46-1$ and 46-2) will be divided into two sections, and two glove boxes (47-1 and 3-1) will be divided into three and four sections, respectively. In addition, twenty-three glove boxes will be separated from the conveyor systems in Rooms 19, $22,25,34,36,37$, and 39 . Sectioned glove boxes shall be blanked with a metal plate.

- Install metal plates (reference Drawing H-2-25995) in all glove ports.

- Install protective covers on all bag ports.

- Disconnect all service lines except glove box exhaust.

- Decontaminate glove box exterior surfaces as necessary. Fix nonsmearable contamination by best method. Flammable solvents are not expected to be used for decontamination; however, should the use of flammable or toxic agents be necessary, the Facility Manager shall contact Industrial Safety for advice and guidance.

- Attach lifting eyes or other: hardware to facilitate handling during removal operations.

\subsection{GLOVE BOX REMOVAL}

There are seventy-nine (79) glove box sections, representing a volume of 12,000 cubic feet, to be removed for burial. These are described in Attachment 4; a detailed sequence of removal activities is shown in 
Attachment 5. Legs, other projections, and attachments shall be removed to reduce the void volume and to improve packaging efficiency. Glove boxes will be removed from the facility after disconnecting and blanking the exhaust ductwork. Removal routes are shown on Attachment 2. Glove box removal shall be planned so that disconnecting the exhaust system, removal from the building and placing in the burial vault shall be a continuous operation.

Glove box removal shall not be scheduled, or shall not proceed, when weather conditions (wind, rain, etc:) would affect the safety of operations. The 231-Z Facility Manager will make this determination. If the removal sequence for glove boxes which have been disconnected from the building exhaust system cannot be completed for weather or other reasons, the disconnected glove boxes shall be protected in a manner that assures contamination control.

In the course of removing the glove boxes, portions or all the walls in seven rooms will be permanently removed. The wall structure varies from room to room and includes block, plasterboard, and sheetmetal. It is anticipated that the waste wall materials will be surveyed and released by Radiation Monitoring and transported to the Central Landfill for disposal. Questionable material will be transported to the Industrial waste Trench.

Contaminated equipment such as vacuum pumps, hydraulic systems, and refrigeration equipment that are external to, but attached to, glove boxes, shall be buried with the glove box if practical. Any such equipment disconnected from the glove box will be blanked in a manner that assures contamination control. Such separated equipment will be placed in burial vaults for disposal. Major equipment items, such as large hydraulic presses, which are part of the glove box system but primarily external to the glove box will be decontaninated where practical and made available as excess equipment. Where decontamination and release is not possible the contamination shall be fixed by the best method and the equipment transported to the Industrial waste Trench for disposal. 


\subsection{EXHAUST SYSTEM AND SERVICE LINES REMOVAL}

Included here are the ductwork from the glove boxes to the secondary filters, the 26 secondary filter cages, the ductwork to the final filter, the final filter bank, the exhaust fans, and the stack. These items, shown in Attachment 3, represent approximately 4,500 cubic feet of contaminated waste to be buried and are described in Attachment 4. Also included are obsolete service lines; i.e., electrical conduit, compressed air, inert gas supply, water cooling, air sampling and other miscellaneous lines. For the most part, these lines are painted. As such, they may not be unconditionally released by Radiation Monitoring and therefore must be handled as contaminated waste. However, they do not represent significant additional volume in that either there will be room in the glove box burial vaults for these items or they will be transported to the Industrial Waste Trench. The secondary filter cages may be removed from the system as soon as the glove boxes which they service have been removed. These items will be monitored for significant plutonium holdup in a manner similar to the glove boxes. Where significant plutonium is detected, the filter will be removed for recovery. "The secondary filter cages are located in the duc. level but extend through the first floor ceiling. The cages are part of the original building services; during facility construction the concrete duct level. floor (first floor ceiling) was poured around them. In some zones of the building these floors are 12-inch thick reinforced concrete. The floor will have to be chipped out to remove the cages.

The ductwork between the secondary filters and the final filter also presents some problem, since it consists of relatively long welded sections. While flanged sections and transitions do exist they usually are not located where it would be most convenient for sectioning for efficient packaging. Greenhouse techniques will be used for ductwork cutting operations where contamination control considerations warrant.

Note: If unsuspected plutonium deposits are discovered in exhaust or service lines, criticality safety controls must be established. 


\subsection{CONTAMINATED DRAINAGE SYSTEM REMOVAL/CONTAINMENT}

There are seventy-five (75) floor drains in the laboratory that carried contaminated liquid to the 200-West crib system at some time in the facility's history. The drains are identified as the $D-4$ system on the reference drawings. These drains now carry very low level or potentially contaminated water to the Z-16 crib. The entire laboratory drainage system was recently dye-tested and the contaminated $\mathrm{D}-4$ system clearly identified. Pertinent drawings (H-2-64100, Sheets 1-4, Plumbing and Drainage 231-Z Building) were made "as-built." Each drain will be cut off below floor level and permanently sealed. All related drain lines leaving the facility and going to the sump tank area, weir box, and Z-16 crib will be excavated and burled as contaminated waste. The $D-1$ (sanitary), D-2 and $D-3$ systems (process drains discharging to the Z-16-U-10 swamp) will remain in service. These drains must be surveyed for possible contamination. It may also be necessary to seal and abandon a portion of these systems.

The two 231-W-151 tanks located in a concrete pit to the east of the 231-Z Building contain contaminated liquid. Sludge samples indicate that Tank 2 contains plutonium ( 185 grams). A criticality safety procedure will be established for emptying the tanks. The empty tanks and related piping will be left in the pit, the pit filled with earth and topped with gravel. If necessary, a burial site designation request will be prepared.

\subsection{OBSOLETE EQUIPMENT DISPOSAL}

A variety of uncontaminated laboratory and ventilation equipment and instrumentation will become obsolete as restoration progresses. The equipment will be excessed following standard property disposal procedures.

\subsection{AI ARM SYSTEMS REMOVAL}

The criticality detector and alarm system will be salvaged as will the criticality dosimeter system. The continuous alpha air monitoring system will also be salvaged. All alpha radiation monitoring equipment will be 
excessed or transferred. The glove box fire detection and alarm system will be removed and buried or excessed as appropriate. The laboratory fire detection alarm and sprinkler system will be left in place. The public address system, laboratory phone system, and laboratory evacuation alarm system will also be left in place. The off-shift door alarm system will be removed from service, as will all motion detectors and other alarms installed for physical security of nuclear materials.

\subsection{FACILITY RESTORATION}

The amount of restoration work required will vary considerably from room to room. Unneeded floor, ceiling, and wall penetrations will be patched and/or sealed. Each room will be completely surveyed for radioactive contamination using a special low-energy gamma scintillation probe and analyzer. Benches, ductwork, equipment and service lines will be moved, as necessary, to permit thorough surface area monitoring. .Contaminated areas shall be cleaned to the extent technically and economically feasible and certainly to a nonsmearable level. The following decontamination standards shall apply:

- Maximum Smearable

Zero

- Maximum Fixed (unpainted)

$0.1 \mu \mathrm{Ci} / 100 \mathrm{~cm}^{2}(220 \mathrm{~d} / \mathrm{m})$

- Maximum Fixed (under paint)

$10 \mu \mathrm{Ci} / 100 \mathrm{~cm}^{2}(22,000 \mathrm{~d} / \mathrm{m})$

Nonsmearable but still contaminated areas shall be painted. A document shall be prepared to identify and describe in detail all painted-over contamination. This record shall include room number, location within room, surface area involved, contamination level prior to and after cleaning and painting, and color of paint and number of coats applied. Decontamination techniques and decontamination decision levels will utilize information available from the ongoing Hanford Decontamination and Decommissioning Program. Floor areas affected by equipment removal shall be patched or tiled to match the balance of the laboratory. The interior of the facility shall be painted. 
Note: The 231-z facility has been in continuous service for over thirty years. During that time there have been many contamination incidents. Documentation of these incidents is not considered sufficiently reliable or complete to know beyond reasonable doubt what floor and wall areas may have contamination which has been painted over. Stripping all surfaces bare and repainting are not recommended. It is believed to be an acceptable risk to operate the laboratory "cold" with facility procedures that would require Radiation Monitoring coverage for all facility modifications where painted surfaces would be disturbed. Routine surveillance by Radiation Monitoryng should also be adopted to search for contamination which might work or wear its way to the surface.

In addition to the internal restoration work described above, the Z-plant exclusion area fence shall be relocated to exclude the $231-Z$ Building. 


\subsection{SPECIAL CONSIDERATIONS}

The phaseout of the DMA program, the decontamination/restoration of the 231-Z facility, and the initiation of new R\&D programs will occur on an overlapping time schedule. Careful planning will be required to assure 1) minimum interference during the transition from the fissile material-classified mode of operation to the anticipated nonradioactive material mode of operation, 2) completion of the decontamination/restoration in a timely and economical manner, and 3) that all pertinent PNL and ERDA requirements are met. Most of the areas of concern have been discussed in other sections of this document but are summarized again here.

\subsection{SECURITY}

Classified work is expected to continue in the facility through midFY77. Above-threshold quantities of plutonium will be handled in the facility during the same period. The present security and physical safeguard controls must be rigidly maintained during this period. Several equipment removal routes require that alarmed doors be temporarily removed from service or that openings be provided in the security perimeter wall. These openings must be sealed off-shift or full time patrol surveillance provided. The sealing method shall satisfy PNL and ERDA security and shall be at least equivalent to that used during the Consolidated Maintenance and Storage Addition Project (BCP-062).

\subsection{RADIATION PROTECTION}

The 231-Z Building General Radiation Work Procedures will cover most of the operations. Unique or unexpected circumstances may require preparation of a special Radiation Work Procedure (RWP). Radiation Monitoring requirements will be extensive, particularly during FY77, and additional monitoring staff will be assigned to the facility as required. Data collected by Radiation Monitoring will provide the basis for decisions on 
equipment removal, burial or salvage, decontamination and restoration, and future facility operating requirements. Dosimetry requirements will be reviewed periodically as staff assignments change.

\subsection{VENTILATION AND AIR BALANCE}

The proper control of ventilation and air balance is crucial to safe working conditions in the laboratory. Interior wall removal will require adjustment to air supply and exhaust controls. The temporary removal of wa11 panels may necessitate restrictions on glove box operations and movement of nuclear materials. At the completion of the project a complete rebalance of the factlity velliliation systcm will be required.

\subsection{CRITICALITY SAFETY}

Removal of the liquid from the two 231-W-151 tanks will present a direct serious criticality safety problem and will require formal evaluation by PNL criticality safety staff. Several other less direct potential problem areas must be given consideration. These include:

- washing down of "dry" glove boxes. If it becomes necessàry to use significant quantities of solutions to reduce internal contamination of- a "dry" glove box, then limits on volume of solution and size of vessels may be necessary.

- disposal of oil and hydraulic fluid. In the disposal of fluids from glove boxes consideration must be given to the possibility of these fluids containing significant quantities of plutonium.

- special packages for plutonium-bearing scrap. If special packages or containers are required, then new criticality safety limits may be neoded.

- discovery of a concealed plutonium deposit. A special criticality safety procedure may be necessary if, during evaluation of a glove box, exhaust or service line, unsuspected deposits of plutonium are discovered. 


\subsection{ALARM SYSTEMS}

GTove box fire alarm detectors will be removed from service as the glove box is deactivated and prepared for removal from the building. All other alarm systems will remain in service until project completion.

\subsection{NUCLEAR MATERIALS MANAGEMENT}

The current schedule of monthly and physical inventories of nuclear materials will be maintained. Disposal of glove boxes, filter cages, and certain equipment items will require careful attention to measurement of plutonium holdup and preparation of appropriate disposal documentation. By the end of FY77, the entire nuclear material inventory will be transferred to recovery or to other ERDA contractors.

\subsection{PROPERTY DISPOSAL}

Hundreds of property inventory items will be buried, transferred to excess or salvage, or otherwise relocated. Preparation of appropriate documentation for approval of these transactions is an important responsibility of project management.

\subsection{PROJECT MANAGEMENT}

The Materials Department will assign sufficient management, engineering and technician staff to the project to assure prompt response to the needs of the various PNL and contractor organizations involved. Checksheets, shown in Attachment 6 , shall be maintained to assist in monitoring work progress and for use in report preparation. 
THIS PAGE

\section{WAS INTENTIONALLY LEFT BLANK}




\subsection{TIME SCHEDULE AND COST ESTIMATE}

The completion schedule and total cost of the decontamination and restoration project will depend on the rate at which funding is provided. A firm funding plan for these activities has not been established. The cost estimate shown in Table 1 assumed a total funding level of $\$ 525 \mathrm{~K}$ for FY76 and FY76T, with the balance of funds provided in FY77, and project completion anticipated by September 30, 1977. Funding at a lower rate seems probable; completion of the project will be delayed until FY78, and costs will probably escalate by $1-2 \%$ of the total below for every month's delay. The final schedule and cost will be heavily dependent on the timing of authorization of FY77 funds. The total cost estimate of $\$ 4,761 \mathrm{~K}$ was used as the basis for the cost/schedule plans of Attachment 7. Revisions will be required when a firm funding plan is developed. A work schedule is shown in Attachment 8.

TABLE 1. Estimated Cost of Decontamination and Restoration (thousands of dollars)

\begin{tabular}{lcccc}
\multicolumn{1}{c}{ Organization } & FY76-76I & FY77 & Total* \\
\cline { 1 - 2 } PNL & 305 & 1076 & 1381 \\
JA Jones Construction Co. & $\underline{220}$ & $\underline{3160}$ & $\underline{3380}$ \\
$\quad$ Totals & 525 & & 4236 & 4761
\end{tabular}

*Includes $25 \%$ contingency and $13 \%$ escalation and assumes a 11 necessary funds will be provided early in FY77. 
THIS PAGE

\section{WAS INTENTIONALLY LEFT BLANK}




\subsection{WORKING REFERENCE DOCUMENTS}

The following documents and specifications are pertinent to the decontamination and restoration of the $231-2$ facility:

1. Schedule 189, "Decontamination and Restoration of the $231-Z$ Facility," Budget Activity No. NM-25-03, April 1975.

2. J. D. Anderson, Specifications and Standards for the Packaging, Storage, and Disposal of Richland Operations Solid Wastes, ARH-3032, Atlantic Richfield Hanford Company, Richland, WA, April 29, 1974.

3. EERDA Manual Chapter 0511, "Radioactive Waste Management."

4. ERDA Manual Chapter 0524 Appendix, "Standards for Radiation Protection."

5. R. A. Kennedy, Design Criteria - Transuranic Dry Waste Burial Containers, ARH-2239, Atlantic Richfield Hanford Company, Richland, WA, March 15, 1972.

6. W. R. Heald, Proposed Use of Fiberglass Reinforced Polyster (FRP) Plywood Containers for Transuranic Burial, ARH-3061, Atlantic Richfield Hanford Company, Richland, WA, April 2, 1.974.

7. CE-0948-P1, "Procurement Specification for Fiberglass Reinforced Plastic (FRP) Plywood Retrievable Container Modules," Rev. No. 3, 1-17-75, Vitro Engineering.

8. 231-Z Building General Radiation Work Procedure, 8-20-75.

9. ERDA Manual Chapter 0529, "Safety Standards for Packaging of Fissile and Other Radioactive Materials." 
ATTACHMENT 1

FIRST FLOOR ARRANGEMENT

23]-Z BUILDING 
ATTACHMENT - 1

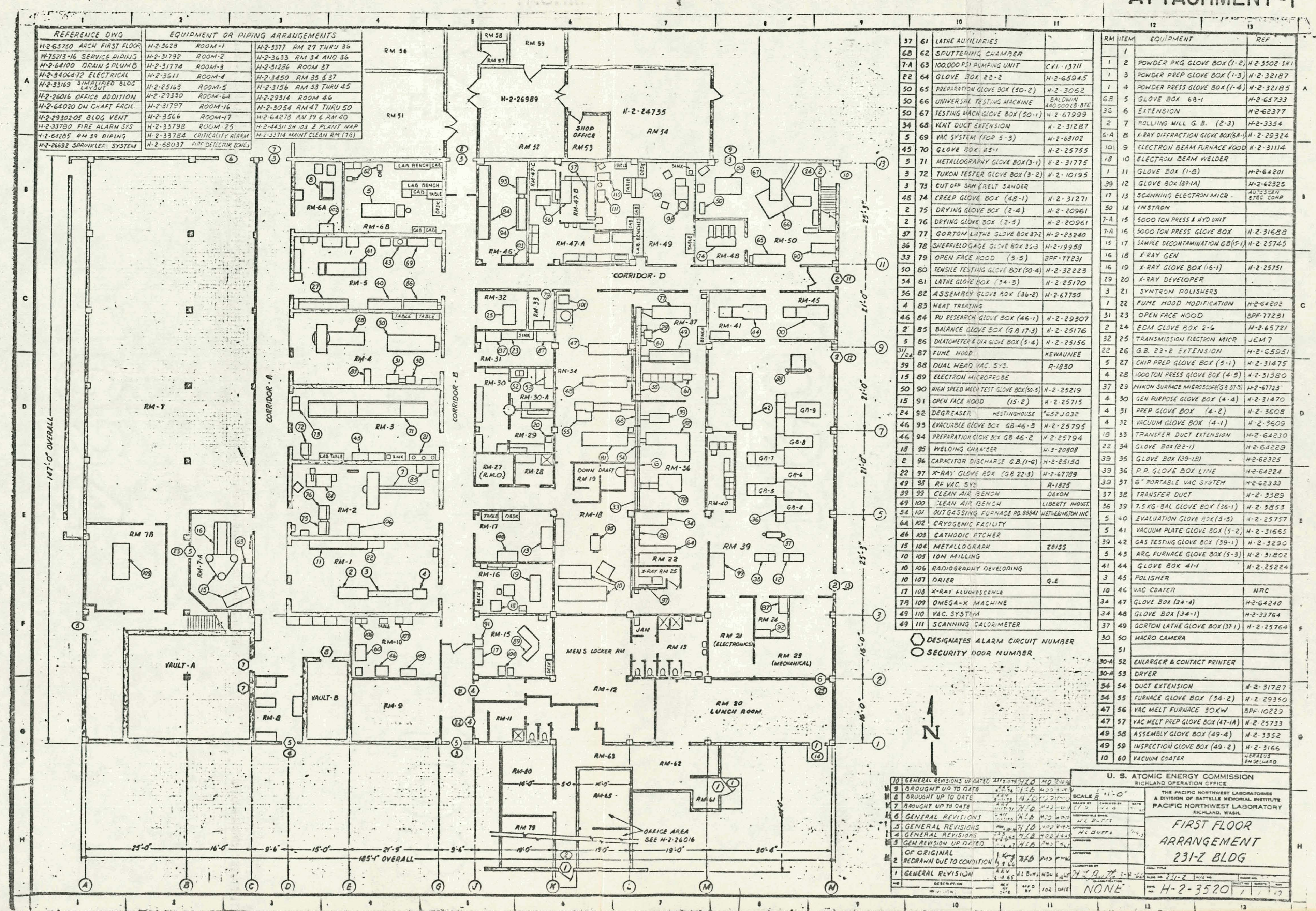


ATTACHMENT 2

FIRST FLOOR

EQUIPMENT EXIT ROUTES 


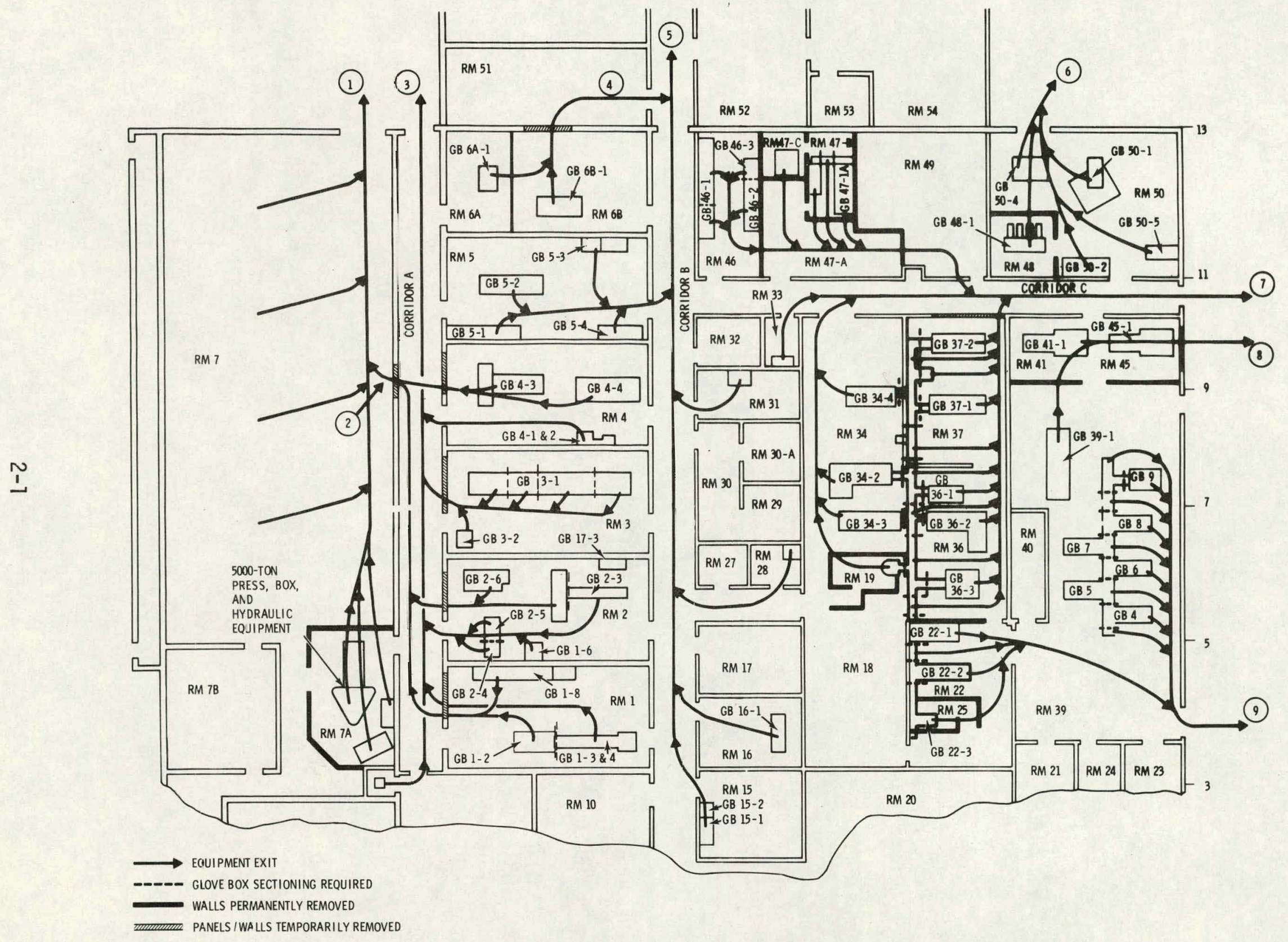

FIRST FLOOR EQUIPMENT EXIT ROUTES 
ATTACHMENT 3

DUCT LEVEL

EQUIPMENT EXIT ROUTES 


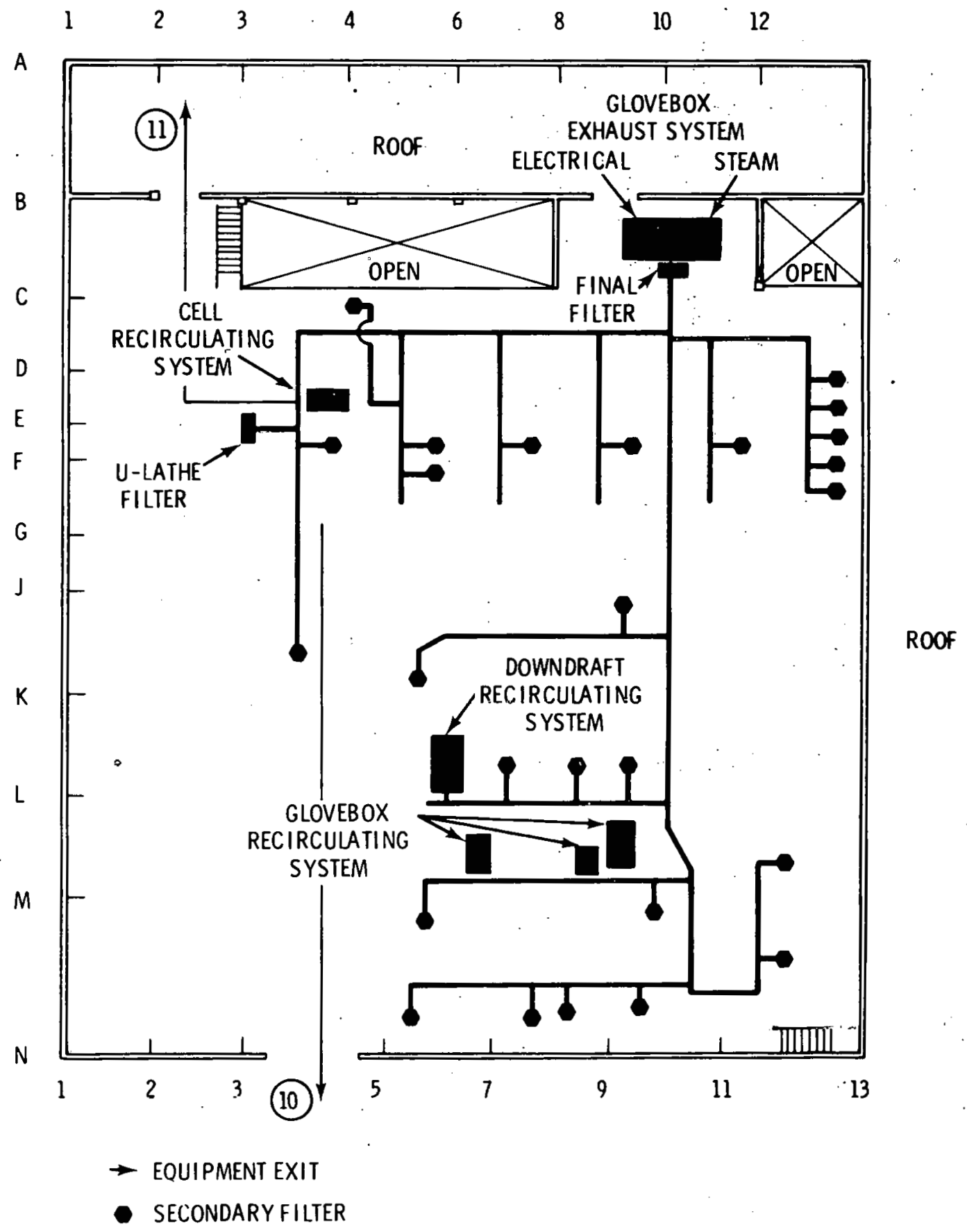

DUCT LEVEL EQUIPMENT EXIT ROUTES 
ATTACHMENT 4

SUMMARY OF GLOVE BOXES

TO BE REMOVED:

DIMENSIONS AND EXIT ROUTES 


\section{ATTACHMENT 4}

SUMMARY OF GLOVE BOXES

TO BE REMOVED:

DIMENSIONS AND EXIT ROUTES

$\frac{\text { Room No. }}{1} \cdot \frac{\text { Glove Box }}{1-8(A)}$

$\frac{\text { Dimensions }}{\text { Length }} \frac{\text { Width }}{\text { Height }}$

$\frac{\text { Ft. }}{15} \frac{\text { In. }}{1} \frac{\frac{\text { Width }}{2}}{\frac{\text { Ft. }}{9}} \frac{\frac{\text { Height }}{\text { Ft. }}}{6} \frac{\text { In. }}{3} \quad \frac{\text { Exit Route }}{2}$

$1 \cdot 1-8(B)$

$\begin{array}{lllllll}4 & 0 & 2 & 4 & 5 & 0 & 2\end{array}$

$1 \quad 1-3(A)$

$1 \quad 1-3(B)$

$1 \quad 1-4$

$2 \quad 2-4$

$2 \quad 2-5$

$2 \quad 2-6$

$2 \quad 2-3(A)$

$2 \quad 2-3(B)$

$2 \cdot 1-6$

$3 \quad 3-2$

3 3-1 (A)

3 3-1 (B)

$3 \quad 3-1(C)$.

$3 \quad 3-1$ (D)

$4 \quad 4-3$

$\begin{array}{lllllll}9 & 0 & 3 & 4 & 7 & 3\end{array}$

$\begin{array}{llllll}11 & 0 & 3 & 5 & 3 & 0\end{array}$

$\begin{array}{llllll}3 & 7 & 2 & 8 & 3 & 6\end{array}$

$\begin{array}{llllll}4 & 6 & 3 & 0 & 3 & 0\end{array}$

$\begin{array}{llllll}4 & 3 & 3 & 0 & 3 & 0\end{array}$

$\begin{array}{llllll}11 & 0 & 3 & 11 & 5 & 2\end{array}$

$\begin{array}{llllll}4 & 6 & 7 & 7 & 4 & 4\end{array}$

$\begin{array}{llllll}11 & 3 & 2 & 1 & 2 & 10\end{array}$

3

$\begin{array}{lllllll}3 & 6 & 3 & 5 & 3 & 4 & 3\end{array}$

$\begin{array}{lllllll}4 & 1 & 3 & 9 & 5 & 2 & 3\end{array}$

$\begin{array}{llllllll}9 & 2 & 4 & 2 & 3 & 6 & 3\end{array}$

$\begin{array}{lllllll}5 & 1 & 4 & 8 & 5 & 0 & 3\end{array}$

$\begin{array}{lllllll}9 & 5 & 4 & 5 & 3 & 0 & 3\end{array}$

$\begin{array}{lllllll}8 & 2 & 4 & 6 & 3 & 7 & 3\end{array}$

$\begin{array}{lllllll}12 & 5 & 3 & 9 & 4 & 8 & 2\end{array}$

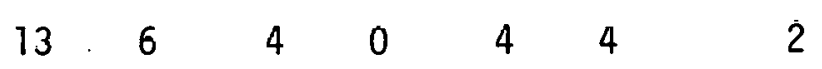

$4 \quad 4-4$

$\begin{array}{llllll}4 & 5 & 2 & 3 & 5 & 6\end{array}$

. 3

$4 \quad 4-1$

$\begin{array}{llll}3 & 10 & 2 & 5\end{array}$

$\begin{array}{llll}13 & 10 & 2 & 4\end{array}$

$\begin{array}{llll}9 & 8 & 3 & 3\end{array}$

$\begin{array}{lllllll}3 & 10 & 2 & 2 & 3 & 8 & 5\end{array}$

$5 \quad 5-3$

5 - 5-4

$6 A \quad 6 A-1$

$6 B \quad 6 B-1$

$\begin{array}{llllll}9 & 6 & 2 & 9 & 4 & 3\end{array}$

5

$\begin{array}{lllllll}4 & 0 & 4 & 6 & 3 & 3 & 4\end{array}$

$\begin{array}{llllll}9 & 7 & 3 & 10 & 6 & 10\end{array}$

4 
Attachment 4 (cont'd)

\begin{tabular}{|c|c|c|c|c|c|c|c|c|}
\hline \multirow[b]{2}{*}{ Room No. } & \multirow[b]{2}{*}{ Glove Box } & \multicolumn{2}{|c|}{ Length } & \multicolumn{2}{|c|}{ Width. } & \multicolumn{2}{|c|}{ Height } & \multirow[b]{2}{*}{ Exit Route } \\
\hline & & Ft. & In. & $\overline{\mathrm{Ft}}$. & In. & $\overline{F t .}$ & In. & \\
\hline $7 A$ & $7-1$ & 1.4 & 0 & 4 & 3 & 4 & 9 & 1 \\
\hline 15 & $15-1$ & 4 & 6 & 2 & 3 & 3 & 2 & 5 \\
\hline 15 & Open Front Hood & 2 & 0 & 2 & $1=$ & 2 & 8 & 5 \\
\hline 16 & $16-1$ & 7 & 6 & 3 & 3 & 4 & 5 & 5 \\
\hline 19 & Downdraft Table & 3 & 6 & 2 & 0 & 3 & 4 & 7 \\
\hline 22 & $22-2$ & 10 & 9 & 3 & 0 & 6 & 4 & 9 \\
\hline 22 & $22-1$ & 8 & 8 & 4 & 1 & 8 & 9. & 9 \\
\hline 22 & Conveyor & 3 & 2 & 1 & 9 & 2 & 8 & 9 \\
\hline 25 & $22-3$ & 4. & 8 & 12 & 0 & 2 & 8 & 9 \\
\hline 31 & Open Front Hood & 4 & 2 & 2 & 4 & 5 & 0 & 5 \\
\hline 33 & Open Front Hood & 4 & 0 & 2 & 4 & 5 & 2 & 7 \\
\hline 34 & $34-4$ & 11 & 4 & 3 & 10 & 8 & 1 & 7 \\
\hline 34 & $34-2$ & 11 & 4 & 3 & 9 & 3 & 8 & 7 \\
\hline 34 & $34-3$ & 12 & 4 & 3 & 10 & 5 & 8 & 7 \\
\hline 36 & $36-3$ & 11 & 6 & 4 & 8 & 9 & 3 & 7. \\
\hline 36 & $36-2(A)$ & 7 & 10 & 4 & 0 & 8 & 0 & 7 \\
\hline 36 & $36-2(B)$ & 8 & 10 & 3 & 8 & 6 & 9 & 7 \\
\hline 36 & $36-1 \quad(A)$ & 7 & 3 & 3 & 1 & 4 & 6 & 7 \\
\hline 36 & $36-1$ (B) & 3 & 0 & 1 & 0 & 3 & 6 & 7 \\
\hline 36 & Conveyor (A) & 8 & 3 & 2 & 0 & 2 & 0 & 7 \\
\hline 36 & Conveyor (B) & 5 & 5 & 2 & 0 & 2 & 0 & 7 \\
\hline 36 & Conveyor (C.) & 11 & 3 & 2 & 0 & 3 & 1 & 7 \\
\hline 36 & Conveyor (D) & 4 & 10 & 2 & 0 & 2 & 8 & 7 \\
\hline 37 & $37-1$ & 12 & 7 & 3 & 9 & 8 & 4 & 7 \\
\hline 37 & $37-2$ & 13 & 0 & 4 & 6 & 6 & 6 & 7 \\
\hline 37 & $37-3$ & 2 & 7 & 2 & 9 & 2 & 4 & 7 \\
\hline 37 & Conveyor & 22 & 2 & 1. & 9 & 2 & 8 & 7 \\
\hline 39 & $39-1$ & 14 & 9 & 4 & 7 & 4 & 0 & 8 \\
\hline 39 & $39-9$ & 9 & 0 & 4 & 3 & 6 & 8 & 9 \\
\hline 39 & $39-8$ & 10 & 0 & 4 & 2 & 10 & 0 & 9 \\
\hline
\end{tabular}


At tachment 4 (cont'd)

\begin{tabular}{|c|c|c|c|c|c|c|c|c|}
\hline \multirow[b]{2}{*}{ Room No. } & \multirow[b]{2}{*}{ Glove Box } & \multicolumn{2}{|c|}{ Length } & \multicolumn{2}{|c|}{ Width } & \multicolumn{2}{|c|}{ Height } & \multirow[b]{2}{*}{ Exit Route } \\
\hline & & Ft. & $\underline{\underline{I n} .}$ & Ft. & $\underline{I n}$. & Ft. & $\underline{\text { In. }}$. & \\
\hline 39 & $39-7$ & 7 & 6 & 4 & 2 & 7 & 4 & 9 \\
\hline 39 & $39-6$ & 10 & 1 & 4 & 2 & 4 & 2 & 9 \\
\hline 39 & $39-5$ & 7 & 6 & 4 & 2 & 7 & 4 & 9 \\
\hline 39 & $39-4$ & 10 & 0 & 5 & 8 & 6 & 0 & 9 \\
\hline 39. & Conveyor & 10 & 4 & 2 & 3 & 2 & 5 & 9 \\
\hline 41 & $41-1$ & 9 & 10 & 4 & 0 & 7 & 2 & 8 \\
\hline 45 & $45-1$ & 10 & 2 & 4 & 0 & 7 & 2 & 8 \\
\hline 46 & $46-1 \quad(A)$ & 10 & 3 & 2 & 6 & 3 & 2 & 7 \\
\hline 46 & $46-1$ (B) & 8 & 7 & 2 & 6 & 4 & 2. & 7 \\
\hline 46 & $46-2$ & 8 & 4 & 2 & 7 & 4 & 8 & 7 \\
\hline 46 & $46-3$ & 6 & 5 & 2 & 6 & 3 & 4 & 7 \\
\hline 47 & $47-1$ & 8 & 0 & 3 & 10 & 10 & 0 & 7 \\
\hline 47 & $47-1 A$ & 10 & 9 & 2 & 5 & 3 & 2 & 7 \\
\hline 47 & Transfer Duct & 3 & 10 & 2 & 0 & 1 & 8 & 7 \\
\hline 48 & $48-1$ & 8 & 5 & 2 & 2 & 7 & 8 & 6 \\
\hline 50 & $50-2$ & 9 & 0 & 2 & 5 & 3 & 0 & 6 \\
\hline 50 & $50-5$ & 6 & 1 & 2 & 5 & 4 & 10 & 6 \\
\hline 50 & $50-1$ & 4 & 10 & 2 & 9 & 4 & 3 & 6 \\
\hline 50 & $50-4$ & 5 & 6 & 7 & 4 & 9 & 0 & 6 \\
\hline Duct Level & 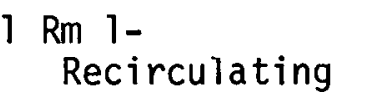 & 10 & 1 & 3 & 7 & 7 & 1 & 11 \\
\hline $\mathrm{DL}$ & $36-3(A)$ & 7 & 7 & 3 & 2 & 2 & 6 & 10 \\
\hline UL & $3 \overline{7}-1 \quad(A)$ & 7 & 4 & 3 & 2 & 2 & 7 & 10 \\
\hline $\mathrm{DL}$ & $37-2$ (A) & 8 & 2 & 5 & 1 & 4 & 7 & 10 \\
\hline $\mathrm{DL}$ & Filter Cages (26) & 3 & 0 & 3 & 0 & 4 & 0 & 10 \\
\hline $\mathrm{DL}$ & Final Filter & 6 & 6 & 6 & 0 & 6 & 6 & 10 \\
\hline $\mathrm{DL}$ & Ductwork & 45 & & 4" & dia & & & 10 \\
\hline $\mathrm{DL}$ & Ductwork & 500 & & $8^{\prime \prime}$ & dia & & & 10 \\
\hline $\mathrm{DL}$ & Ductwork & 200 & & $10^{\prime \prime}$ & dia & & & 10 \\
\hline $\mathrm{DL}$ & Ductwork & 400 & & $14 "$ & dia & & & 10 \\
\hline
\end{tabular}


Attachment 4 (cont'd)

\begin{tabular}{|c|c|c|c|c|c|c|}
\hline \multirow[b]{2}{*}{ Room No. } & \multirow[b]{2}{*}{ Glove Box } & Length & \multicolumn{2}{|c|}{ - Width } & Height & \multirow[b]{2}{*}{ Exit Route } \\
\hline & & Ft. In. & Ft. & $\underline{I n}$. & Ft. In. & \\
\hline DL & Ductwork & 35 & $16 "$. & dia & & 10 \\
\hline DL & Ductwork & 10 & $20 !$ & dia & $\therefore$ & 10 \\
\hline DL & Ductwork & 35 & $16 "$ & dia & & 10 \\
\hline DL & Ductwork & 10 & $20 "$ & dia & & 10 \\
\hline $\mathrm{DL}$ & Ductwork & 39 & $22^{\prime \prime}$ & dia & & 10 \\
\hline $\mathrm{DL}$ & Ductwork & 100 & $24 "$ & dia & & 10 \\
\hline $\mathrm{DL}$ & Exhaust. Stack & 50 & $32^{\prime \prime}$ & dia & & Outside \\
\hline $\mathrm{DL}$ & Exhaust Fäns (2) & 8 & 3 & 6 & 7 & 10 \\
\hline
\end{tabular}




\section{ATTACHMENT 5 \\ SEQUENCE AND ESTIMATED COMPLETION SCHEDULE OF ACTIVITIES}


SEQUENCE OF ACTIVITIES AND ESTIMATED COMPLETION SCHEDULE

DECONTAMINATION AND RESTORATION OF THE 231-Z FACILITY

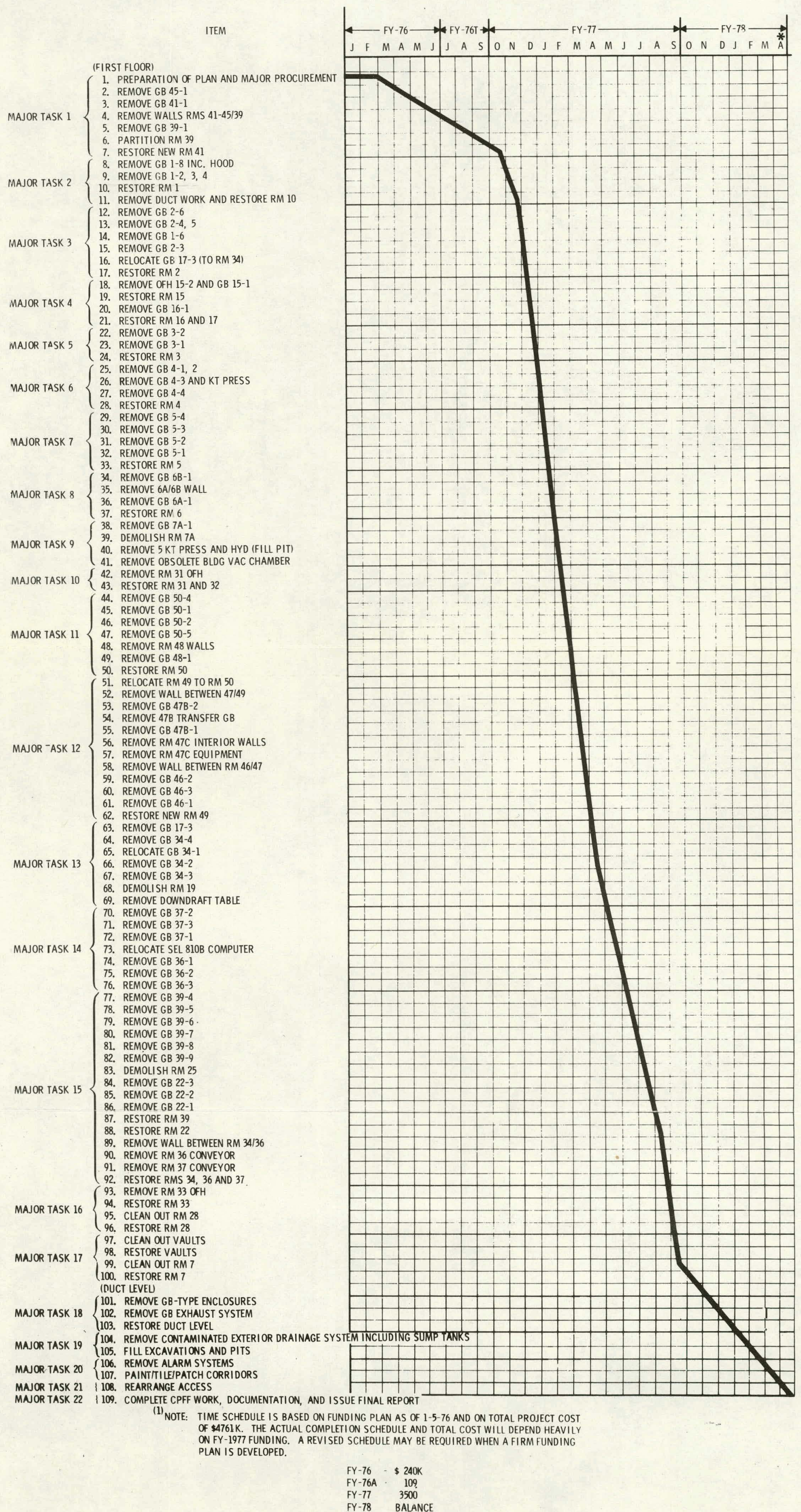


ATTACHMENT 6

SAMPLE CHECK SHEETS 
SAMPLE 6-A. GLOVE BOX CHECK SHEET

1. Glove box identification Room HEW \#

2. Other HEW equipment in/or attached to glove box:

3. 0il drained from vacuum or hydraulic systems

4. - Attached equipment to be removed:

5. Cleanout completed Date

6. Plutonium value assigned Date

7. Disposal request prepared Ref. Document No.

8. Sectioning required Pieces

9. Outside dimensions: a) b)

c)

d)

10. Fire alarm/detector disconnected

11. E-4 disconnected

12. Exit route

13. Placed in burial vault No. 
A) Vault No.

B) Weight: Empty

Loaded Contents

Weight

Pu Value

1.

$?$.

3.

4.

5.

6.

7.

C) Total Pu Content

D) Date Sealed

E) Solid Waste Burial Document No.

F) Burial Location

G) Date Buried 
SAMPLE 6-C. ROOM CHECKSHEET

1. Room No.

2. Glove boxes to be removed for burial:

Identification

HEW No.

Date Removed Pu Value
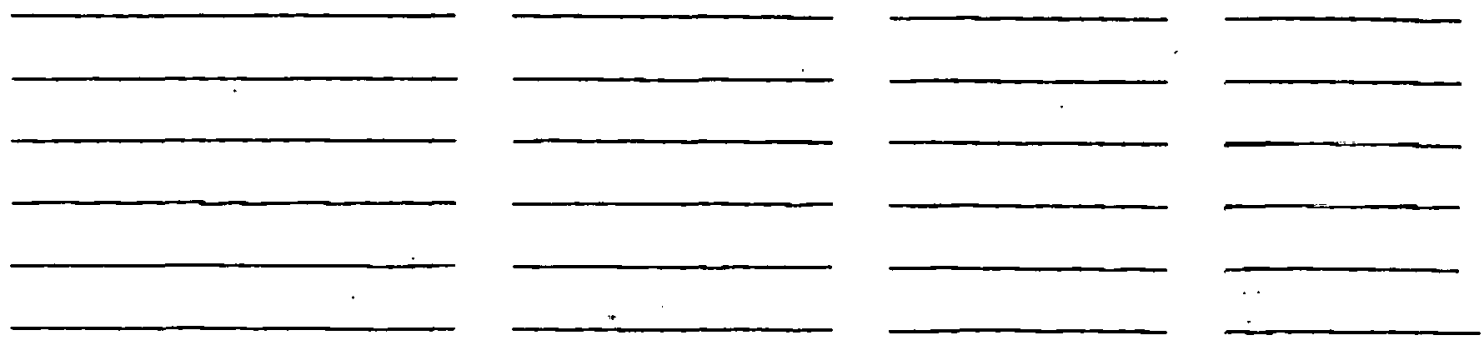

3. Other equipment requiring removal:

Identification

Hew No.

Disposition Date Removed
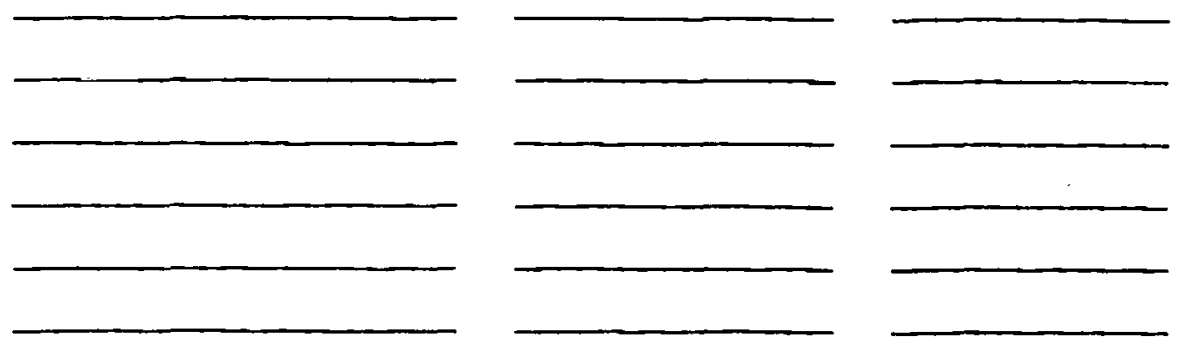

4. Wall, door or floor modifications required:

5. Service lines to be removed:

Description

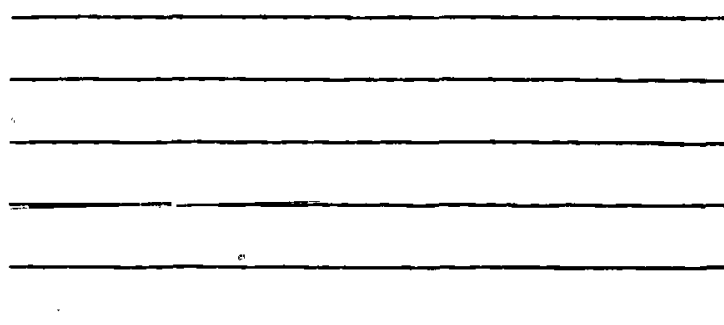

Date Completed

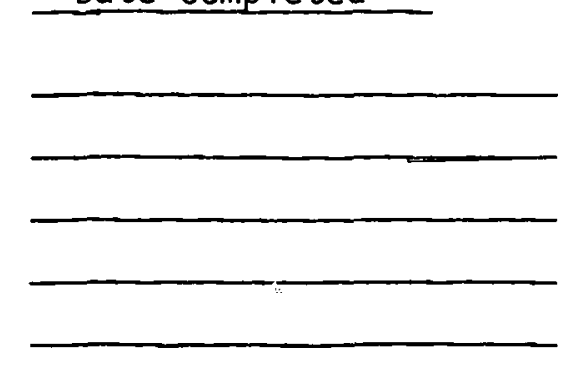

6. No. of floor drains to be sealed:

Date completed: 
SAMPLE 6-C. (Cont'd)

7. Alarm systems to be removed:

Description

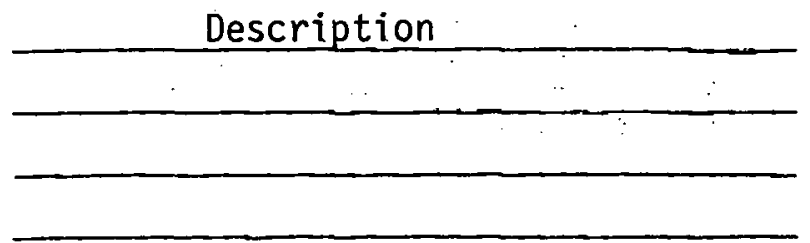

8. Results of RM Survey:

9. Description of covered contamination:

Photographic Record

10. Finishing required:

11. Room Restoration Complete -- Date
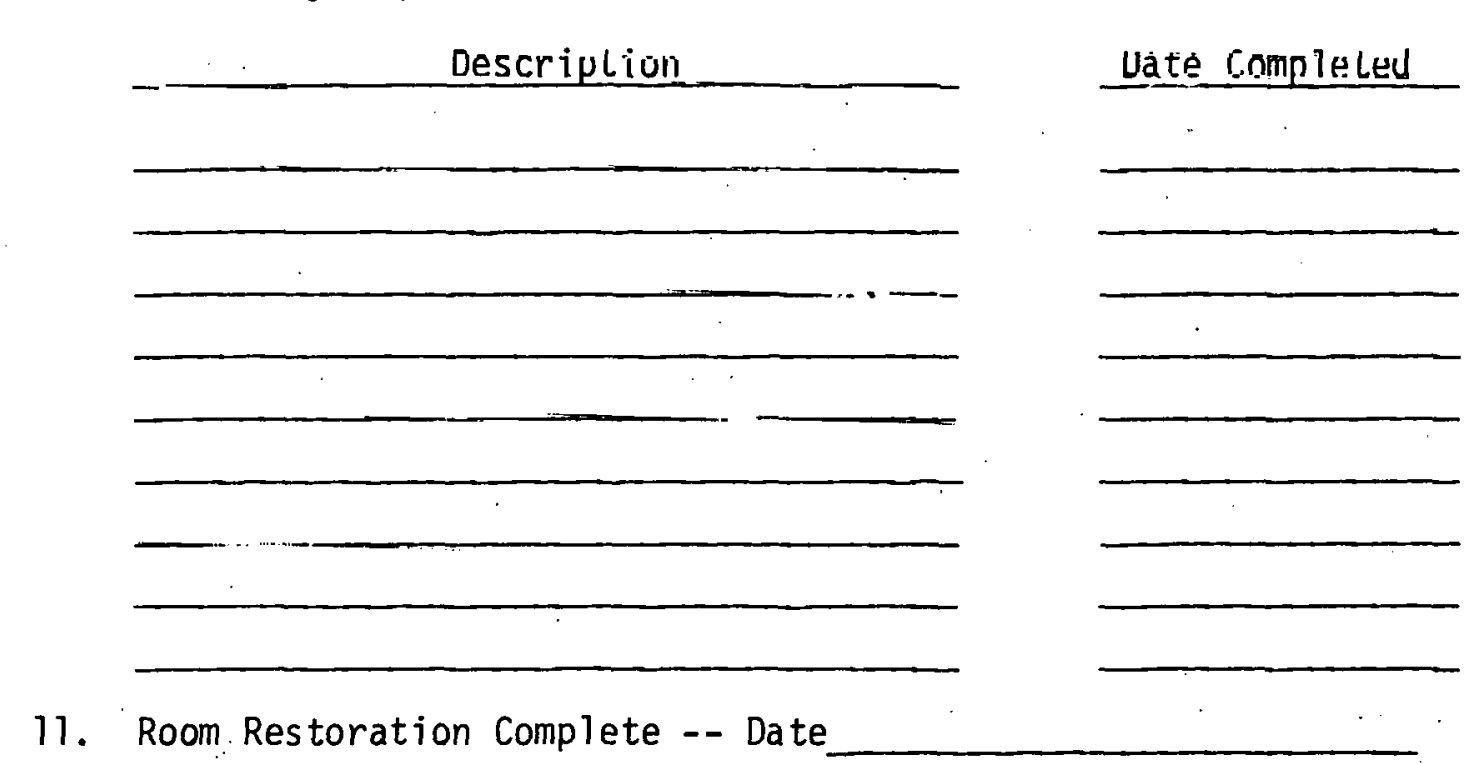

Date Completed

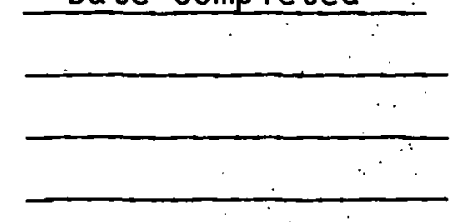

Survey Record No. 
ATTACHMENT 7

COST/SCHEDULE DATA 
MONTHLY COST PLAN (\$K)

DECONTAMINATION AND RESTORATION OF 231-Z

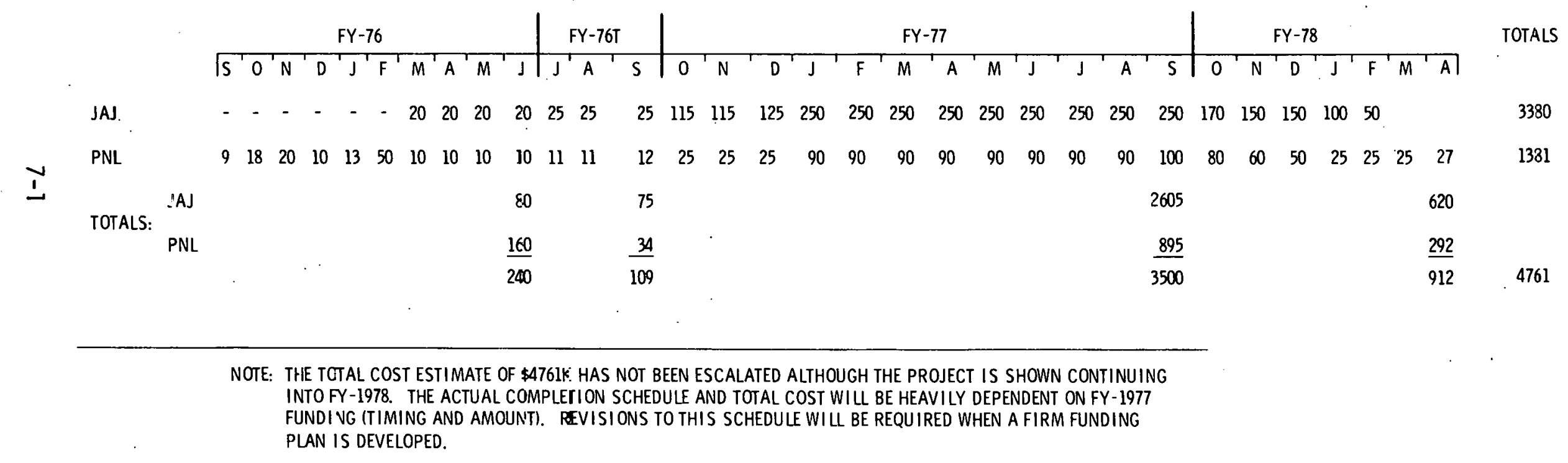




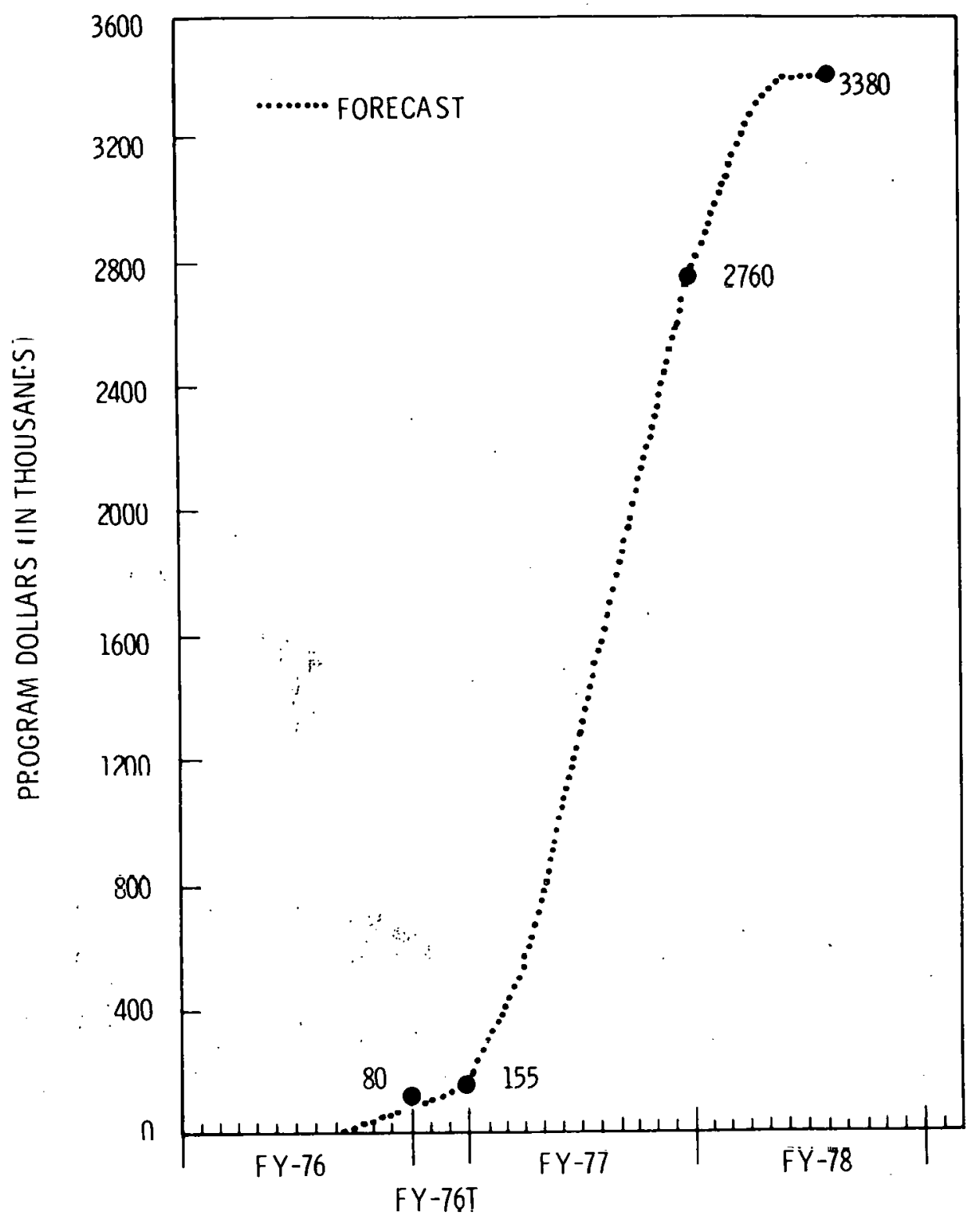

J. A. JONES COSTS:

DECONTAMINATION AND RESTORATION OF 237-Z 


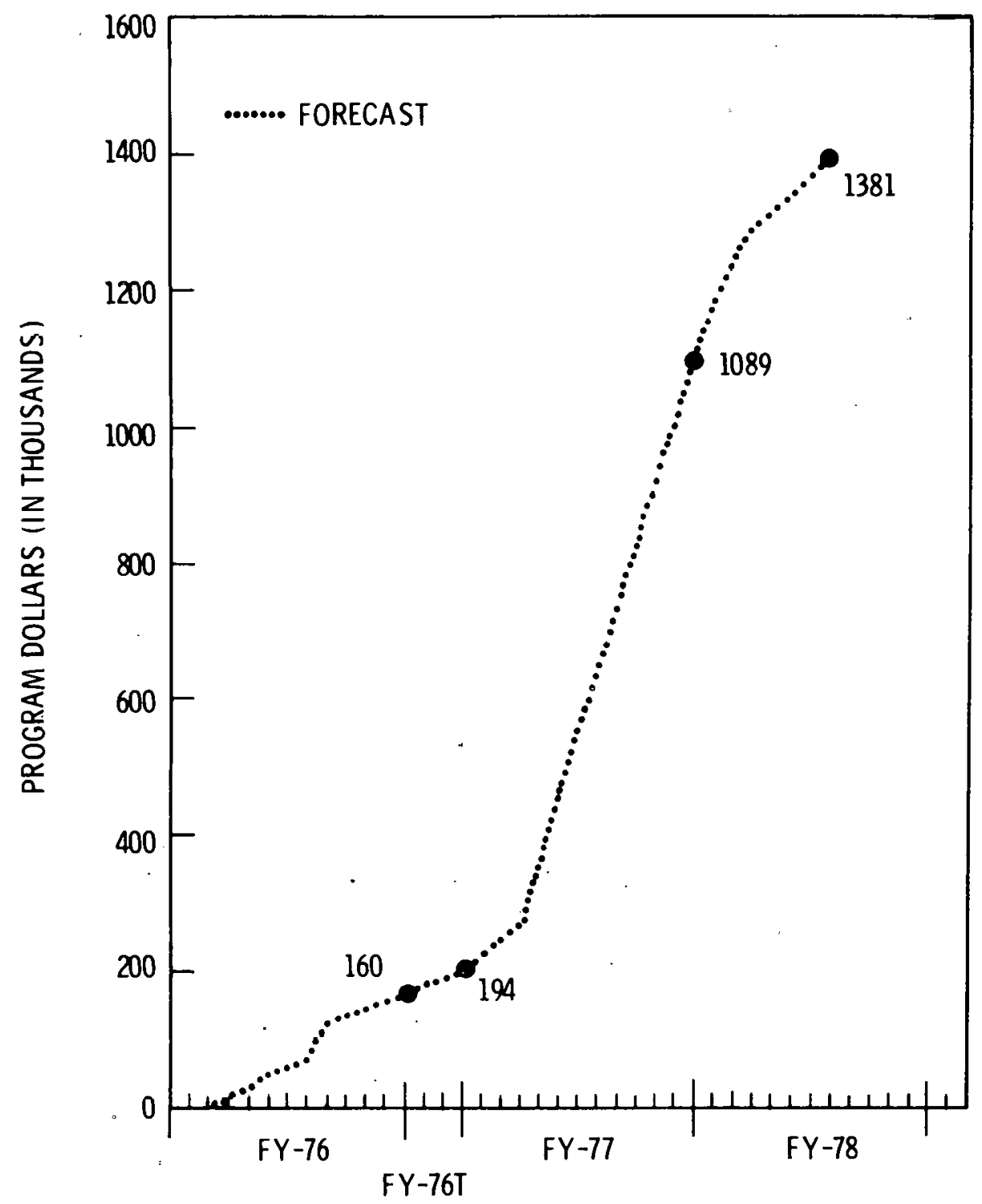

PACIFIC NORTHWEST LABORATORY COSTS:

DECONTAMINATION AND RESTORATION OF 231-Z 


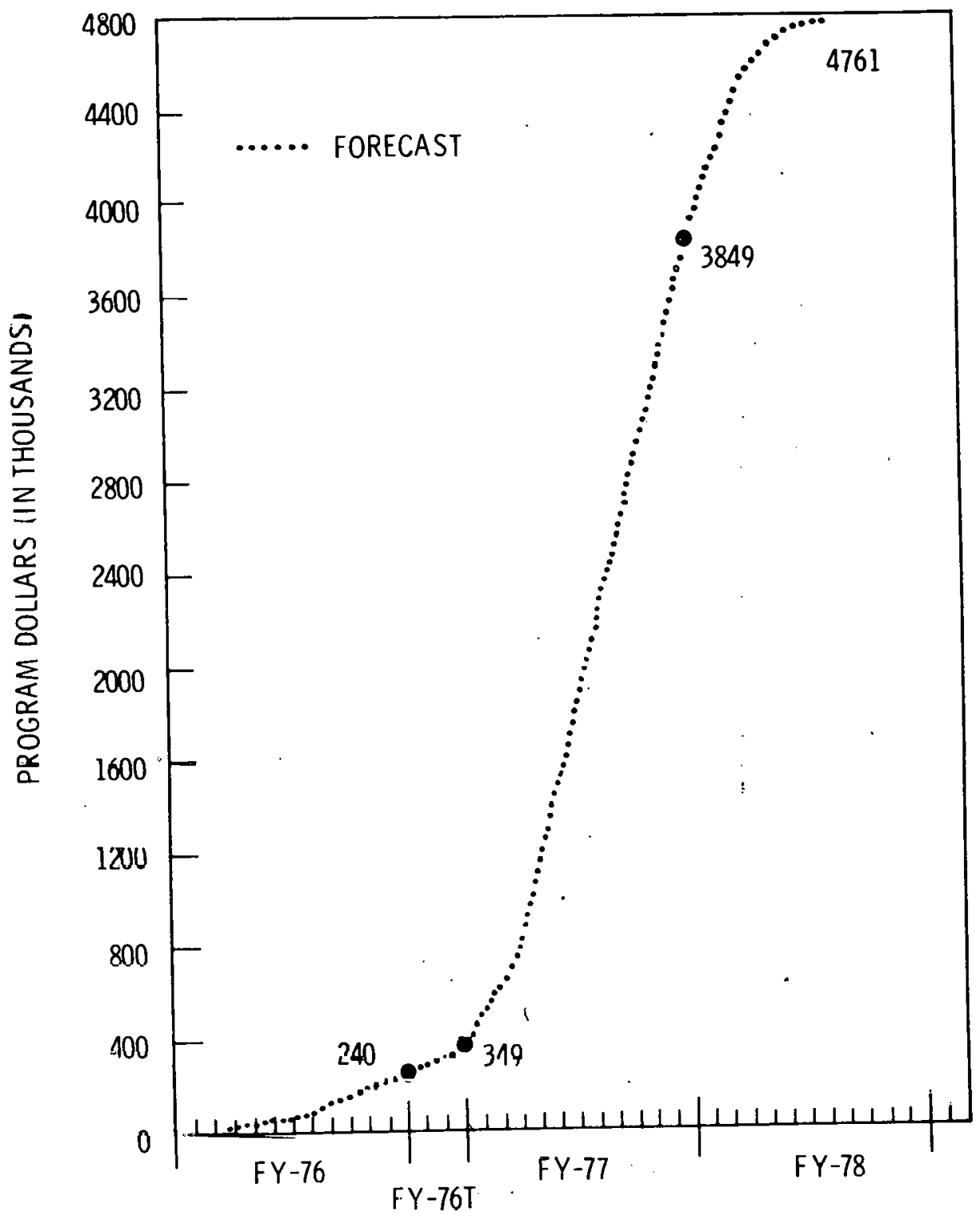

TOTAL COSTS:

DECONTAMINATION AND RESTORATION OF 231-L 
MAJOR TASKS, COSTS, AND ESTIMATED PERCENT OF. PROJECT DECONTAMINATION AND RESTORATION OF 231-Z

\begin{tabular}{|c|c|c|c|c|c|}
\hline \multirow[b]{2}{*}{ MAJOR TASK } & \multirow{2}{*}{$\begin{array}{c}\text { SEQUENCE }^{(1)} \\
\text { STEPS } \\
\end{array}$} & \multirow{2}{*}{$\begin{array}{l}\text { ESTIMATED } \\
\text { COST }(\$ K)\end{array}$} & \multirow[b]{2}{*}{$\%$ OF PROJECT } & \multicolumn{2}{|c|}{ CUMULATIVE } \\
\hline & & & & $\%$ & $\operatorname{cosT}(\$ K)$ \\
\hline 1 & $1-7$ & 379 & 8.0 & 8.0 & 379 \\
\hline 2 & $8-11$ & 119 & 2.5 & 10.5 & 498 \\
\hline 3 & $12-17$ & 129 & 2.7 & 13.2 & 627 \\
\hline 4 & $18-21$ & 61 & 1.3 & 14.5 & 688 \\
\hline 5 & $22-24$ & 106 & 2.2 & 16.7 & 794 \\
\hline 6 & $25-28$ & 135 & 2.8 & 19.5 & 929 \\
\hline 7 & $29-33$ & 156 & 3.3 & 22.8 & 1085 \\
\hline 8 & $34-37$ & 114 & 2.4 & 25.2 & 1199 \\
\hline 9 & $38-41$ & 101 & 2.1 & 27.3 & 1300 \\
\hline 10 & $42-43$ & 39 & 0.8 & 28.1 & 1339 \\
\hline 11 & $44-50$ & 220 & 4.6 & 32.7 & 1559 \\
\hline 12 & $51-62$ & 302 & 6.3 & 39.0 & 1861 \\
\hline $13^{\circ}$ & $63-68$ & 253 & 5.3 & 44.3 & 2114 \\
\hline 14 & $70-76$ & 615 & 12.9 & 57.2 & 2729 \\
\hline 15 & $77-92$ & 605 & 12.8 & 70.0 & 3334 \\
\hline 16 & $93-96$ & 73 & 1.5 & 71.5 & 3407 \\
\hline 17 & $97-100$ & 404 & 8.6 & 80.1 & 3811 \\
\hline 18 & $101-103$ & 625 & 13.1 & 93.2 & 4436 \\
\hline 19 & $104-105$ & 140 & 2.9 & 96.1 & 4576 \\
\hline 20 & $106-107$ & 66 & 1.4 & 97.5 & 4642 \\
\hline 21 & 108 & 67 & 1.4 & 98.9 & 4709 \\
\hline 22 & 109 & 52 & 1.1 & 100 & 4761 \\
\hline
\end{tabular}




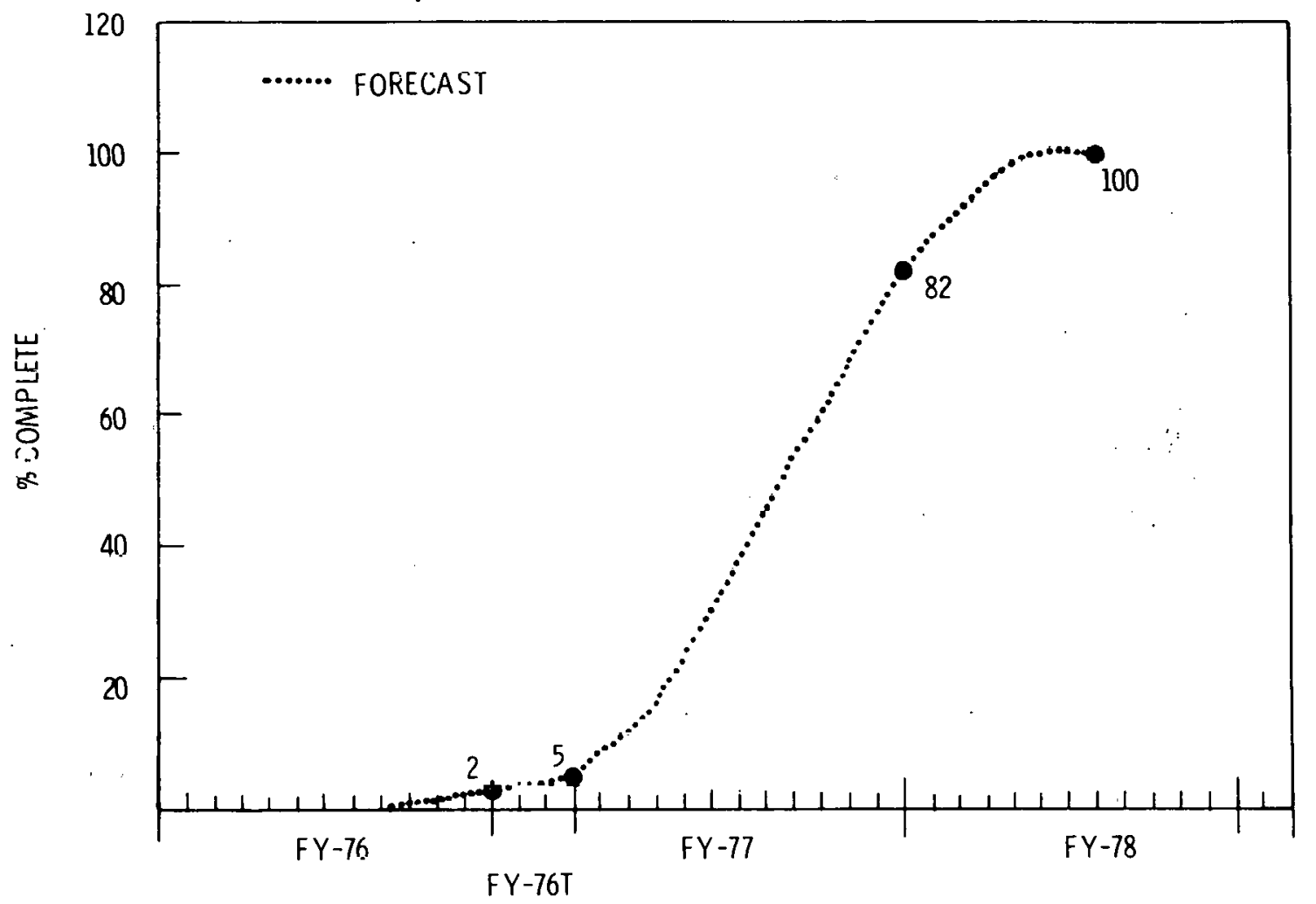

COMPLETION SCHEDULE:

DECONTAMINATION AND RESTORATION OF 231-Z 


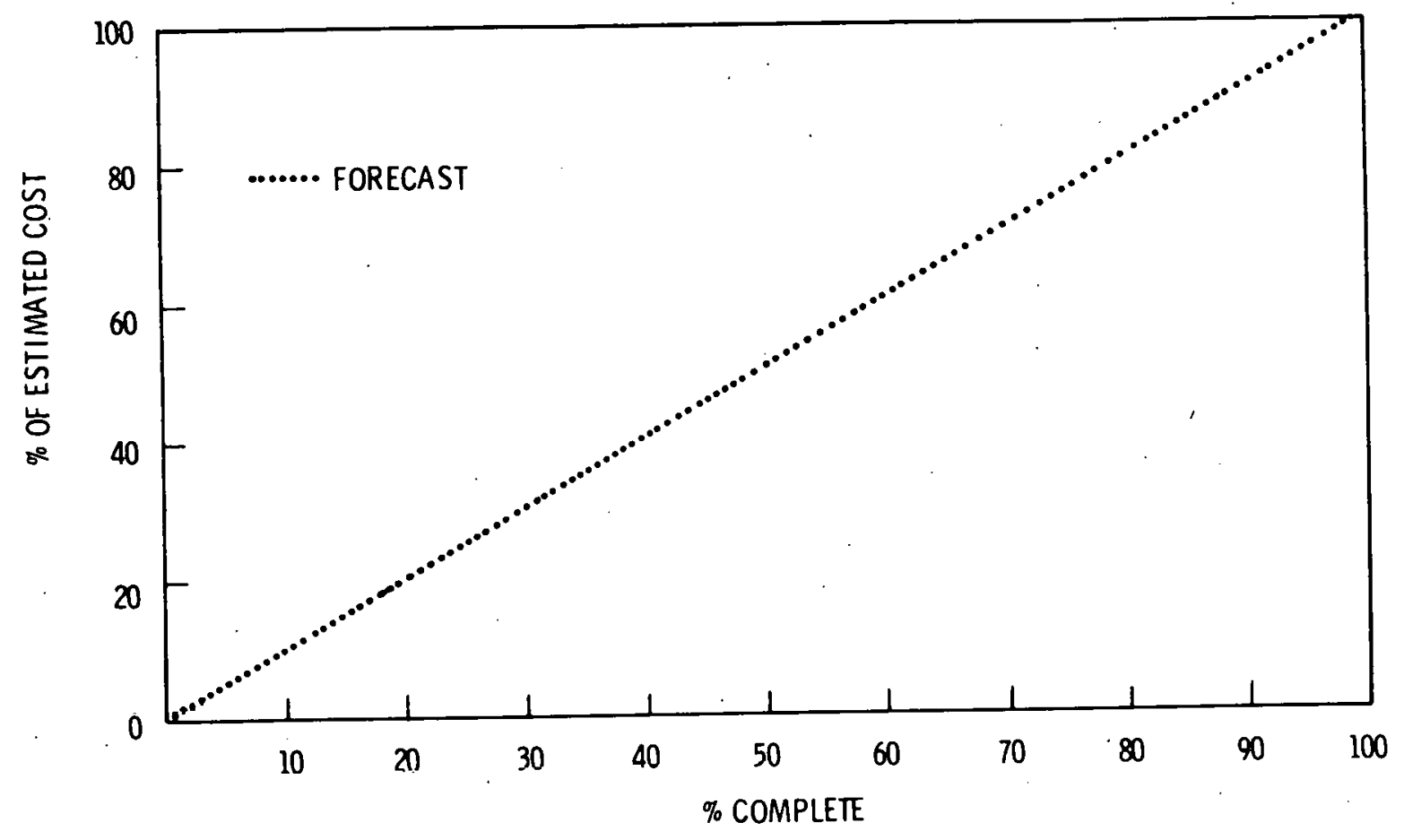

COST/BUDGET COMPARISON:

DECONTAMINATION AND RESTORATION OF $231-Z$ 
ATTACHMENT 8

WORK SCHEDULE 
WORK SCHEDULE

DECONTAMINATION AND RESTORATION OF THE 231-Z FACILITY

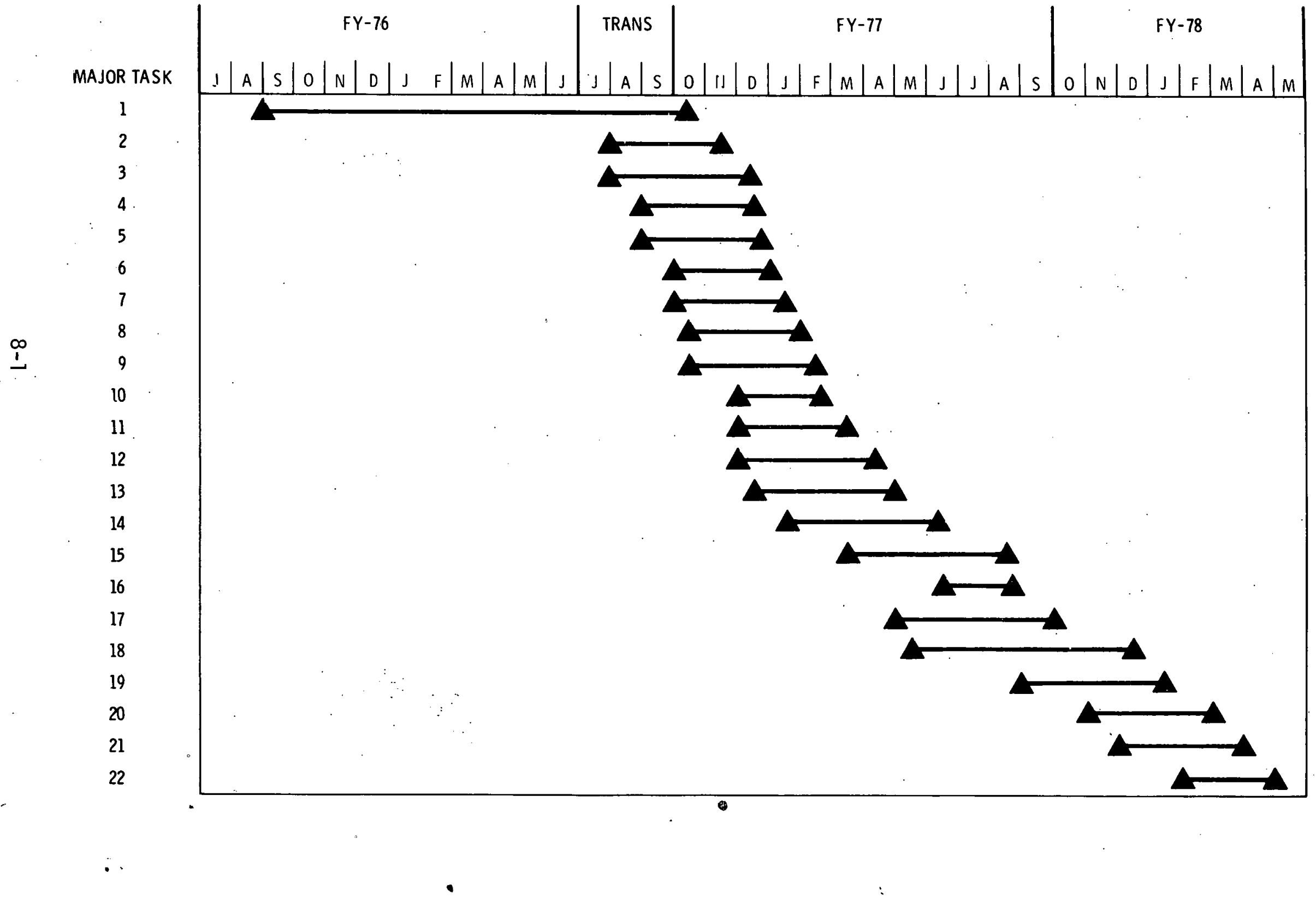




\section{DISTRIBUTION}

No. of

Copies

OFFSITE

1 A. A. Churm

ERDA Chicago Patent Group

U.S. ERDA

9800 South Cass Avenue

Argonne, IL 60439

1 Col. F. C. Cobb

U.S. ERDA Division of Military Application

Office of Laser and Isotope

Separation Technology

A-364

Washington, DC 20545

27 ERDA Technical Information Center

\section{ONSITE}

9 ERDA Richland Operations Office
J. F. Bagley
P. A. Craig
R. B. Goranson
P. G. Holsted
K. H. Jackson
D. K. Jones
B. J. Melton
B. L. Nicoll
P. G. Rhoades

8 Atlantic Richfield Hanford Company

N. L. Gross

G. A. Hirst

J. W. Jordon

J. H. Kennedy

M. N. Raile
No. of

Copies

Atlantic Richfield Hanford Company (Continued)

M. L. Short

C. P. Sutter

G. A. Nicholson

2 J.A. Jones Construction Company

I. Cornelius

A. Prince

74 Battelle-Northwest

R. B. Abrams

V. C. Asmund (10)

J. H. Bender

J. L. Boyd

C. L. Brown

H. L. Butts (10)

T. D. Chikalla

H. E. Clouse

J. P. Crewdson

G. M. Dalen

R. L. Dillon

J. C. Dunn

J. W. Finnigan

J. J. Fuquay

H. R. Gardner

S. Goldsmith

M. M. Hankins

K. M. Harmon

K. R. Heid

H. L. Henry

J. G. Holt

D. S. Jackson

J. J. Jech

R. S. Kemper

R. R. King (10)

H. V. Larson

J. W. Litchfield

R. P. Marshall 
No. of

Copies

Battelle-Northwest - (Continued)

E. D. McFal1

M. H. Napora

R. D. Nelson

D. G. Olander

D. E. Olesen

H. C. Riches

W. D. Richmond

J. M. Selby

J. H. Soehnlein

R. W. Stewart

C. N. Unruh

D. L. Weaver

0. J. Wick

M. A. Williams

Technical Information (3)

Technical Publications (2) 